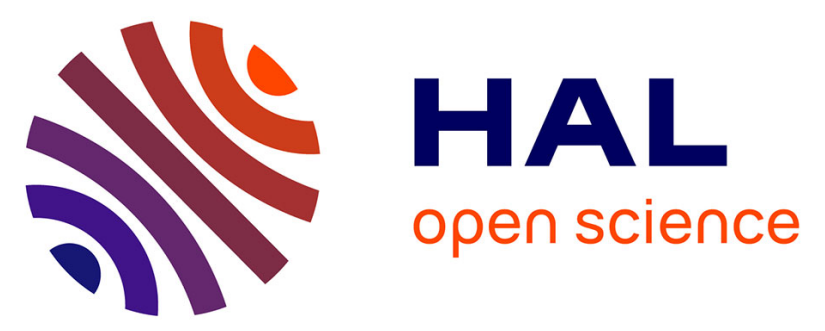

\title{
Investigating of labelling and detection of transthyretin synthetic peptide derivatized with naphthalene-2,3-dicarboxaldehyde
}

Mathilde Faure, Sonia Korchane, Isabelle Le Potier, Antoine Pallandre, Claude Deslouis, Anne-Marie Haghiri-Gosnet, Jean Gamby

\section{To cite this version:}

Mathilde Faure, Sonia Korchane, Isabelle Le Potier, Antoine Pallandre, Claude Deslouis, et al.. Investigating of labelling and detection of transthyretin synthetic peptide derivatized with naphthalene2,3-dicarboxaldehyde. Talanta, 2013, 116, pp.8-13. 10.1016/j.talanta.2013.04.060 . hal-00832153

\section{HAL Id: hal-00832153 \\ https://hal.sorbonne-universite.fr/hal-00832153}

Submitted on 10 Mar 2015

HAL is a multi-disciplinary open access archive for the deposit and dissemination of scientific research documents, whether they are published or not. The documents may come from teaching and research institutions in France or abroad, or from public or private research centers.
L'archive ouverte pluridisciplinaire HAL, est destinée au dépôt et à la diffusion de documents scientifiques de niveau recherche, publiés ou non, émanant des établissements d'enseignement et de recherche français ou étrangers, des laboratoires publics ou privés. 


\title{
Investigating of labelling and detection of Transthyretin synthetic peptide derivatized with Naphthalene-2,3-dicarboxaldehyde
}

\author{
Mathilde Faure $^{\mathrm{a}, \mathrm{b}, \dagger}$, Sonia Korchane ${ }^{\mathrm{c}, \dagger}$, Isabelle Le Potier ${ }^{\mathrm{c}}$, Antoine Pallandre ${ }^{\mathrm{c}}$, Claude \\ Deslouis $^{\mathrm{a}, \mathrm{b}}$, Anne-Marie Haghiri-Gosnet ${ }^{\mathrm{d}}$, Jean Gamby ${ }^{\mathrm{a}, \mathrm{b},{ }^{*}}$ \\ ${ }^{a}$ CNRS, Laboratoire Interfaces et Systèmes Electrochimiques, UPR 15, F-75252 Paris, France \\ ${ }^{b}$ UPMC, LISE UPR 15 CNRS ; 4 Place Jussieu, case postale 133, F-75252 Paris, France \\ ${ }^{c}$ Université Paris-Sud, Faculté de Pharmacie, Institut Galien Paris-Sud CNRS UMR 8612, \\ Châtenay-Malabry, France \\ ${ }^{d}$ CNRS, Laboratoire de Photonique et de Nanostructures, UPR20, Marcoussis 91460, France
}

\footnotetext{
* Corresponding author: jean.gamby@upmc.fr: $\quad$ tel: +33144273640 fax: ++33144274074

$\uparrow$ The both authors have equally contributed to this work
} 


\begin{abstract}
Labelling and detection of a synthetic peptide (PN) mimicking a tryptic fragment of interest for the diagnosis of familial amyloidal polyneuropathy have been investigated optically and electrochemically. We decided to covalently label naphtalene-2,3-dicarboxyaldehyde (NDA), a fluorogenic and electroactive molecule on PN. Firstly, the optimization of the labelling chemical reaction was performed by capillary electrophoresis coupled with laser induced fluorescence detection (CE-LIF). The analytical parameters such as separation efficiency and peak area were considered to propose this optimized derivatization reaction. The results obtained allowed us to establish the $\mathrm{pH}$ and ionic strength of the derivatization buffer, the molar ratio between NDA and PN and the reaction time of the labelling. Optimal conditions are obtained when $[\mathrm{NDA}] /[\mathrm{PN}]=40$, buffer $\mathrm{pH}$ of 9 , buffer ionic strength of 70 $\mathrm{mM}$ and reaction time of $15 \mathrm{~min}$. Secondly, differential pulse voltammetry (DPV) and cyclic voltammetry (CV) were also used to characterize NDA-labelled PN and different electroinactive amino acids (histidine, lysine, serine, threonine) which are in the PN sequence. The electrochemical detection experiments demonstrated that the labelled biomolecules could be also easily detected at low concentration. Moreover, the derivatization reaction could be followed to describe more precisely the labelling process of these biomolecules. Optimal conditions for labelling are obtained when $[\mathrm{NDA}]_{\text {total }} /[\mathrm{CN}-]$ ratio $=1$ and $[\mathrm{NDA}]_{\text {total }} /[$ amino acid or peptide $]=100$ with a buffer having a $\mathrm{pH}=9$ on a glassy carbon electrode. In all cases, an obvious oxidation peak for the N-2-substituted-1cyanobenz- $[f]$-isoindole derivative $(\mathrm{CBI})$ has been observed at $0.5-0.7 \mathrm{~V} / \mathrm{SCE}$. The multilabelling of PN and lysine were shown with DPV. We presumed this result to occur because of the shouldered shape of the DPV peak shape. These experiments confirm that NDA can be used as a derivative agent for PN, allowing for electrochemical and fluorescence detections with a limit of detection of labelled PN estimated at $0.2 \mu \mathrm{M}$ and 5 $\mu \mathrm{M}$, respectively.
\end{abstract}

Keywords: Transthyretin; Naphthalene-2,3-dicarboxaldehyde; Capillary electrophoresis; Differential pulse voltammetry. 


\section{Introduction}

The naphtalene-2,3-dicarboxyaldehyde (NDA) is a fluorogenic and electroactive reagent commonly used to covalently react with amino functional group of various molecules (see in Scheme 1). This compound is particularly attractive to tag biomolecules such as peptides and proteins and therefore to create novel diagnostic strategies. The N-2-substituted-1cyanobenz-[f]-isoindole (CBI) derivative represents also another opportunity to collect competitive data with electrochemical [1] or optical detections [2,3,4] In recent years, electrochemical detection (ED) has been used with different techniques of separation, such as liquid chromatography in order to analyze amino acids neuron from Helix Aspersa neuron [5] or several aliphatic amines [6]. Capillary electrophoresis has also been coupled with ED for detection of amino acids in brain homogenate [7], in single erythrocyte [8] and in single mouse peritoneal macrophages [9]. Electrochemical properties of CBI have been utilized to identify compounds from Planorbius corneus dopamine neuron. Detection and separation of amino acids and small peptides can also be carried out in microchips [10]. Electrochemical detection presents some advantages for multi derivatized molecules [11]. Indeed, peptides which bear more than one $\mathrm{NH}_{2}$ group can be derivatized as often as their number of $\mathrm{NH}_{2}$ groups. These multi derivatized amino acids present a self quenching effect and therefore are difficult to detect by fluorescence [12] whereas electrochemical response is not attenuated. This derivative was already used and reported in the literature because of its highly fluorescent and relatively stable properties $[12,13]$. The use of cyanure as nucleophilic in the reaction instead of other one like 2-Mercaptoethanol usually used, permits to obtain the more stable and the best fluorescence intensity for derivative [13].

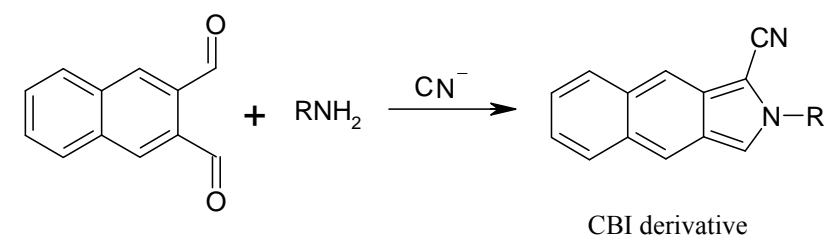

Scheme 1: Derivatization reaction of primary amine by NDA.

Here we will focus on the reaction between the NDA and a small peptide of 22 amino acids (PN) likely to be useful for the diagnosis of transthyretin-related familial amyloïd 
polyneuropathy $[14,15,16]$ (see in Scheme 2). Firstly, in a systematic approach, we study by capillary electrophoresis coupled with laser induced fluorescence (CE-LIF) the influence of some of major parameters to analytically evaluate their influence over the derivatization reaction efficiency. We believe that the following results demonstrate that we optimized the tagging pathway to analyze small biomarkers bearing amino group. Secondly, taking into account the tagging reaction efficiency established by CE-LIF, properties of CBI derivatives which are also electrochemically active have been studied by differential pulse voltammetry (DPV). Indeed, selectivity can be achieved by varying the electrode potential in order to compare characteristics of derivatized peptide and non electroactive amino acids which are in peptide sequence.

\section{PN : Nterm-TSESGELHGLTTEEEFVEGIYK-Cterm}

Scheme 2. Sequence of the studied peptide (PN)

Lysine and threonine have been selected because they are $C$-terminal and $N$-terminal amino acids, respectively. Serine and histidine have been selected because these amino acids are the more acidic and more basic ones, respectively.

\section{Experimental}

2.1. Chemicals and reagents

\subsubsection{Chemicals}

NDA was purchased from Interchim (Montluçon, France). Potassium cyanide, HEPES, boric acid, lysine, serine and threonine were purchased from Sigma Aldrich (Saint-Quentin Fallavier, France). Methanol and sodium hydroxide from VWR (Fontenay-sous-Bois, France) and the PN peptide was obtained from Genepep (Prades le Lez, France), histidine and tyrosine from Alfa Aesar (Karlsruhe, Allemagne).

\subsubsection{Peptide labelling}

The labelling method was inspired and adapted by previous works on NDA labelling $[1,12,13]$. Peptide samples were labeled by adding to $50 \mu \mathrm{L}$ of peptide $\left(2.10^{-4} \mathrm{M}\right.$ in water), $100 \mu \mathrm{L} \mathrm{KCN}$ dissolved in a borate buffer, $150 \mu \mathrm{L}$ borate buffer (ionic strength varying 
from $10 \mathrm{mM}$ to $100 \mathrm{mM}$ and $\mathrm{pH}$ varying from 8 to 10 ) and $100 \mu \mathrm{L}$ NDA in methanol. The mixture was kept at room temperature away from light. The reaction time, $\mathrm{pH}$ and ionic strength of the buffer, the concentration of the NDA and of the KCN were optimized.

2.1. Instrumentation

\subsubsection{Capillary electrophoresis}

A Beckman Coulter PA800 Capillary electrophoresis was coupled with a $442 \mathrm{~nm}$ laser of $42.1 \mathrm{~mW}$ (BFI Optilas France, Evry, France). The capillary electrophoresis instrument was adapted to be compatible with the $442 \mathrm{~nm}$ laser. For that, two different filters were used in the commercial Beckman capillary system: a laser filter (441.6 nm) and an emission filter $(490 \mathrm{~nm})(\mathrm{CVI}$ Melles Griott, Voisins le Bretonneux, France). Those filters were placed in an analogous way to the original filters.

Separations were carried out with fused-silica capillaries (Phymep, Paris, France) of $75 \mu \mathrm{m}$ i.d. having an effective length of $50 \mathrm{~cm}$ and a total length of $60.2 \mathrm{~cm}$. Before each electrophoretic run, the capillary was sequentially flushed with $0.1 \mathrm{M}$ sodium hydroxide (3 $\mathrm{min}$ ), then with MilliQ water ( $3 \mathrm{~min}$ ), and then equilibrated with the separation buffer for 3 min. The analyses were performed at $+25 \mathrm{kV}$, with LIF detection (excitation wavelength, $\lambda \mathrm{ex}=442 \mathrm{~nm})$.

\subsubsection{Electrochemical measurement}

Electrochemical measurements were performed using a Biologic SP-300 electrochemical analysis system with EC-lab software. Experiments were performed with a three-electrode cell configuration. The reference and the counter electrodes were a saturated calomel electrode (SCE) and a platinum grid (Pt), respectively. The working electrode was glassy carbon with an area equal to $0.071 \mathrm{~cm}^{2}$. DPV parameters as modulation time $(100 \mathrm{~ms})$, modulation amplitude $(7.5 \mathrm{mV})$, and scan rate $\left(25 \mathrm{mV} \cdot \mathrm{s}^{-1}\right)$ have been optimized to obtain analytical curves. Baselines were recorded after DPV response with a blank solution.

\section{Results and discussion}

\subsection{Tagging reaction optimization by capillary electrophoresis}

From the literature, it is clear that the chemical and structural aspects of the biomarker are the first parameters to reach high reacting efficiency. Several authors have used $\mathrm{NDA} \backslash \mathrm{CN}^{-}$ 
mixtures for amino acids (AA) and small peptides labelling [17-20]. Their reports were an inspiriting root for our work. However reaction parameters have been optimized to get the best reaction yield for our peptide (22 AA).

We obviously see in Fig. 1 the fluorogenic character of the NDA. In fact, when there is no reaction with the peptide, there is no peak. However, after the peptide derivatization, we logically detect a peak corresponding to the CBI derivative.

In order to develop an efficient derivatization method, the main parameters were fixed by our readings or studies. First, inspired by Hu et al [19], a 1:1 molar ratio of KCN and NDA was fixed for all studies, then we evaluated the yield of the reaction by measuring the peak area when NDA/PN molar ratio changes keeping all the other parameters constant. And in order to keep a pseudo-first-order reaction, we worked with a high excess of NDA compared to PN.

The Fig. S1 in the supplementary material shows the importance of the first studied parameter: the molar ratio between peptide and NDA. We see a net increase in the CE peak area that is characteristic of the tagged peptide, between a NDA/PN molar ratio of 20 and 40 , and the maximum peak area is reached for a ratio equal to 40 . This observation shows that the reaction is quantitative for this ratio. When the NDA/PN ratio is higher than 40 , the main peak area decreases, and it seems that a side peaks appearance is responsible. Indeed, the fluorogenic reagent may react very slowly in different pathways to form fluorescent side products [20]. Those side products can be seen in the Fig. 2 underlining the differences between a 40 and a $100 \mathrm{NDA} / \mathrm{PN}$ molar ratio. In fact, the intensity of the 3.5 min peak is much larger in the ratio 100 than in the ratio 40 . Moreover, at 5.7 min a peak corresponding to the $\mathrm{CBI}$ derivative becomes shouldered when the ratio reaches 100 .

Previous studies revealed that the reaction yield increases when the ionic strength of the buffer solution (borate buffer) increases, certainly due to the catalytic effect of this concentration [12]. Thus, we studied the influence of the ionic strength of the borate buffer (from $10 \mathrm{mM}$ to $100 \mathrm{mM}$ ) on the reaction yield by keeping the NDA/PN ratio and the $\mathrm{pH}$ equal to 40 and 10, respectively. As expected and displayed in Fig. S2 (see supplementary material), we obtained an increase of the peak area when the ionic strength increases. However, on the same time, the separation efficiency dramatically decreases. This can be explained by the analysis buffer characteristics. In fact, all the analysis were performed 
with a $40 \mathrm{mM}$ HEPES buffer $\mathrm{pH}=8$ as background electrolyte (BGE). On the other hand, ionic strength of derivatization solution was increasing that makes its conductivity higher than the BGE's one. This phenomenon leads to a flattening of the peaks. In this context, the best compromise between the reaction yield and the separation efficiency was the buffer ionic strength of $70 \mathrm{mM}$.

The third optimized parameter is the reaction $\mathrm{pH}$. It represents another critical parameter that controls the reaction yield. De Montigny et al [13] reported that the optimum $\mathrm{pH}$ of the reaction depends on the amine's pKa. In this direction, Lunte et al [2] found that the optimum $\mathrm{pH}$ for derivatization was usually near to the analyte $\mathrm{pKa}$. Taking into account the $\mathrm{pKa}$ range of the peptide amine function (from 8.7 to 10.7) and the increase of the fluorescence yield at alkaline $\mathrm{pH}$, we chose to study the reaction on $\mathrm{pH}$ varying between 8.5 and 10.

As presented in Fig. S3 (see supplementary material), an increase of the separation efficiency was observed for $\mathrm{pH}$ ranging from 8.5 to 9.5 , while a decrease of the peak area was observed in this $\mathrm{pH}$ range. When the $\mathrm{pH}$ is higher than 9.5 , the separation efficiency decreased, whereas the peak area increases. In this context, the best compromise between the reaction yield and the separation efficiency was the borate buffer $\mathrm{pH} 9$.

Experiments were carried out to find the optimum reaction time. From the literature we knew that this parameter is another critical one that is correlated with other parameters such as peptide or amino acid concentration, sample volume, composition of the incubating solution [17-21]. The conformation of the peptide is also a factor to take into account because the steric hindrance increases the reaction time. In our work, the optimum reaction time was $15 \mathrm{~min}$. Moreover, the stability of the peptide labelled with NDA was studied, and we found out that it was stable for at least 5 hours in darkness. This latter condition is very important because the photobleaching phenomenon occurs quickly when the sample is light-exposed.

Finally, the sensivity of detection of the CE-LIF method was studied by calculating the limit of detection (LOD) corresponding to a signal-to-noise ratio of 3. In the optimized conditions defined above (reaction time of $15 \mathrm{~min}$, NDA/PN molar ratio equal to 40, ionic strength buffer of $70 \mathrm{mM}$ and $\mathrm{pH}$ buffer equal to 9) the LOD of labeled PN was found to be $5 \mu \mathrm{M}$. 


\subsection{Electrochemical characterization}

The electrolyte support for all experiments is constituted by $100 \mathrm{mM}$ borate buffer in methanol:water mixture $(50: 50 \mathrm{v} / \mathrm{v})$. PN derivatization was followed by differential pulse voltammetry (DPV) at $25 \mathrm{mV} \mathrm{s}^{-1}$. The Figures 3 and 4 display signal differences between $25 \mu \mathrm{M}$ PN alone, $2.5 \mathrm{mM}$ NDA and for online derivation solution constituted by $25 \mu \mathrm{M}$ PN with $2.5 \mathrm{mM}$ NDA in presence of $2.5 \mathrm{mM} \mathrm{KCN}$ in $100 \mathrm{mM}$ electrolyte support at $\mathrm{pH}=9$ (NDA/PN in a molar ratio of 100). No oxidation or reduction peaks was observed for peptide alone. This confirmed that PN peptide was electroinactive in the potential window, in spite of tyrosine presence in $\mathrm{PN}$ sequence which was expected as an electroactive amino acid. Moreover, in this oxidative potential window NDA is also electroinactive (see in Fig. 4). Nevertheless, if we consider a reductive potential window, reduction of two aldehydes groups NDA at $\mathrm{pH} 9$ were observed at $-1.1 \mathrm{~V} / \mathrm{SCE}$ and $-1.3 \mathrm{~V} / \mathrm{SCE}$. In the case of derivatized PN peptide, an oxidation peak was located at $0.55 \mathrm{~V} / \mathrm{ECS}$ corresponding to CBI oxidation. As noted in Fig. 4, CBI oxidation is irreversible in agreement with the literature $[11,22]$. Likewise, there was only one peak and no shouldered peak for CBI. It seemed to confirm the inactivity of tyrosine residue in PN. In the literature, peptides with tyrosine residue show two waves of oxidation, one for tyrosine and one for the isoindole ring of CBI [22]. For example, Nussbaun et al explained that the peak potential of isoindole group was characteristic to the derivatized amino acid or peptide. In order to provide an answer to this hypothesis, derivatization of four amino acids contained in PN sequence were performed for lysine, serine, histidine and threonine at the same concentration for each AA $(25 \mu \mathrm{M})$. Peaks potential for CBI-(lysine), CBI-(serine), CBI-(histidine) and CBI-(threonine) were found at $0.54 \mathrm{~V} / \mathrm{SCE} ; 0.57 \mathrm{~V} / \mathrm{SCE}, 0.59 \mathrm{~V} / \mathrm{SCE}$ and $0.58 \mathrm{~V} / \mathrm{SCE}$, respectively as shown in Fig. 5. Our results shown that lysine which was doubly derivatized was easier to oxidize than histidine and serine. Moreover, amino acids with basic chains like histidine are more easily oxidized than one with neutral or acid chains like serine. Threonine has a chain more acid than the histidine one but more basic than the serine chain.

Furthermore, peak potential is dependent on the chain length and the derivatized $\mathrm{NH}_{2}$ number. In addition PN peak potential occurred approximately at the same peak potential found value that lysine. This seems to demonstrate that PN derivatized is relatively easily 
oxidized. By considering the PN sequence of 22 amino acids (see in Scheme 2), we assume that PN is obviously doubly derivatized, firstly by the threonine and secondly by the second $\mathrm{NH}_{2}$ group of lysine to form a CBI-TSESGELHGLTTEEEFVEGIYK-CBI.

Three different protocols of derivatization were performed with DPV. The first one at $\mathrm{pH}=10$ with $2.5 \mathrm{mM} \mathrm{NDA} / 25 \mu \mathrm{M} \mathrm{PN}$ molar ratio of 100 , the second one at $\mathrm{pH}=9$ with 1 $\mathrm{mM}$ NDA/ $25 \mu \mathrm{M}$ PN molar ratio of 40 , the last one at $\mathrm{pH}=10$ with ratio $1 \mathrm{mM} \mathrm{NDA} / 25$ $\mu \mathrm{M}$ PN molar ratio of 40. As displayed in Fig. 6, CBI derivative oxidation peak was located at $0.55 \mathrm{~V} / \mathrm{SCE}$ for each protocol, whatever the scan rates. These observations underline that any chemical reaction (such as proton transfer) is involved during charge transfer reaction on CBI derivative obtained from peptide. Indeed, the oxidation process of CBI-PN is only due to a loss of electron. Otherwise, peaks intensity would have been found as dependent of the protocol used. The peak area for the first method was found to be equal to $(3.8 \pm$ $0.3) \cdot 10^{-5}$, (3.3 \pm 0.2$) \cdot 10^{-5}$ for the second, and $(3.2 \pm 0.2) \cdot 10^{-5}$ for the third protocol. A comparison for the both $\mathrm{pH}$ at molar ratio of 40 shows a quasi identical area. Moreover, peak area of the first protocol with NDA/PN molar ratio of 100 was found as being more important than the one obtained with NDA/PN molar ratio of 40 . The observed difference was due to the fact that peptide was probably doubly derivatized leading to a self quenching effect, which happened to be annoying with a fluorescence detection but not with an electrochemical detection. The peak can be decomposed into two different peaks, the first one corresponding to the doubly derivatized at $0.55 \mathrm{~V} / \mathrm{SCE}$ and the second one to the simply derivatized at $0.69 \mathrm{~V} / \mathrm{SCE}$, this latter being more difficult to oxidize and having a peak potential more anodic than amino acids because of the chain length. An area of $3.5 \times 10^{-5}$ and $2 \times 10^{-5}$ were found for the doubly and simply derivatized, respectively. Another protocol with low concentration of $\mathrm{PN}(10 \mu \mathrm{M})$ in borate buffer $\mathrm{pH} 10$, and ratio of $40(0.4 \mathrm{mM}$ NDA/ $10 \mu \mathrm{M}$ PN) was studied by DPV. The peak of CBI-PN was also present at $0.55 \mathrm{~V} / \mathrm{SCE}$ and had an area of $(1.9 \pm 0.1) \cdot 10^{-5}$. The peak potential is therefore independent of peptide concentration. When added PN concentration increases, CBI-PN yielded increases too, while the corresponding peak potential position still remains independent of the concentration of CBI-PN. In addition, the peak area increased with concentration of CBI-PN formed. Thereby, we have demonstrated that CBI-PN was quantitative using electrochemical detection as low concentration as $10 \mu \mathrm{M}$ of peptide. 
Finally, the third method at $\mathrm{pH}=10$ with NDA/PN molar ratio of 40 was also studied by cyclic voltammetry leading to the same previous conclusions: no variation on peak potential position when CBI- PN increases and for scan rate variation.

For protocol at $\mathrm{pH}=10$ and $1 \mathrm{mM} \mathrm{NDA} / 25 \mu \mathrm{M}$ PN molar ratio of 40 , variation of peak intensity against time has been investigated. As displayed in Fig. 7, the peak intensity increased as CBI yielded was increasing. Peak intensity was followed after 3, 9 and 15 minutes of derivatization time (Fig. 7A). At the same time, an increase CBI-PN can be correlated to a decrease of the two NDA peaks reduction. As mentioned previously, NDA was electroactive through successive reduction of the two aldehydes groups (see in Fig. 7B). In the other hand, it was an original way for online monitoring of PN derivatization. A time of 3 minutes was sufficient to obtain the formation of CBI-PN. Nevertheless, peak intensity was higher for a derivatization time over 15 minutes in agreement with those obtained with fluorescence detection. Stability of the labelling protocol was also performed by electrochemistry. We observed that the CBI-PN peak was still present at least after 24 hours. After 30min, the CBI peak area represents $98 \%$ of the i value, $97 \%$ after an hour and $80 \%$ after 24 hours. This confirms that the solution has to be kept away from light, then the labeling reaction is stable and the solution can be analyzed by electrochemistry 24 hours after mixing.

\section{Conclusions}

This work describes NDA derivatives of AAs and peptide for quantitative analysis. From this assessment we decided to perform several experiments to optically and electrochemically characterize the label reaction of NDA with AAs involved in peptide PN. The response of derivatives on glassy carbon electrode exhibits excellent electrochemical properties and adequate stability over 24 hours. The labelling reaction was studied by characterizing the resulting labelled molecules with optically and electrochemically characterizations. The measurements are coherent. We notice that the limit of CBI-PN detection is slightly lower for electrochemical measurements $(0.2 \mu \mathrm{M})$ compared to laser induced fluorescence detection $(5 \mu \mathrm{M})$. CBI-AAs can be detected at lower working potential, $+0.5-0.7 \mathrm{~V} / \mathrm{SCE}$, making this approach selective enough and enabling difference between simply or doubly derivatized peptide. These results have demonstrated the 
practical utility of detecting CBI derivatives electrochemically in micro-total analysis ( $\mu$ TAS). Indeed, electrochemical detection is particularly attractive to perform portable $\mu$ TAS. Electrochemical detection could rather simplify the future miniaturized instrument set-up since the popular electrophoretic separations already require electrical parts. Even if it benefits from a good limit of detection, the introduction of optical detection in microfluidic analytical instrument is experimentally rather complicated or bulky.

\section{Acknowledgements}

We are indebted to Myriam Taverna for discussions and access to experimental facilities. This research was supported by the French ANR (Agence Nationale de la Recherche) in the context of the P2N "DIMIPOLE" project. 


\section{References}

[1] M. D. Oates, B. R. Cooper, J. W. Jorgenson, Anal. Chem. 62 (1990) 1573-1577S.

[2] M. Lunte, O. S. Wang, LC GC. 7 (1989) 908-910.

[3] S. W Su, Y.C. Liao, C. W. Whang, J. Sep.Sci, 35 (2012), 681-687

[4] S. Zhao, Y. Song, Y.M. Liu, Talanta 67 (2005) 212-216

[5] C. A. Vyas, S. M. Rawls, R. B. Raffa, J. G. Shackman, J. pharm. Tox. Meth 63 (2011) $119-122$

[6] S. Lamba, A. Pandit, S. K. Sanghi, V. S. Gowri, A. Tiwari, V. K. Baderia, D. K. Singh, P. Nigam, Anal. Chim. Acta. 614 (2008) 190-195.

[7] T. J. O’Shea, R. D.Greenhagen, S. M. Lunte, G. E. Lunte, J. Chromatogr. 593 (1992) 305-312.

[8] Q. Dong, X. Wang, L. Zhu, W. Jin, J. Chromatogr. A. 959 (2002) 269-279.

[9] Q. Weng, W. Jin, Electrophoresis, 22 (2001) 2797-2803.

[10] J. Wang, G. Chen, M. Pumera, Electroanalysis, 15 (2003), 862-865.

[11] S. M. Lunte, T. Mohabbat, O. S. Wong, T. Kuwana, Anal Biochem. 178, (1989), 202207.

[12] B. K. Matuszewski, R. S. Givens, K. Srinivasachar, R. G. Carlson, T. Higuchi, Anal. Chem. 59 (1987) 1102-1105.

[13] P. De Montigny, J. F. Stobaugh, R. S. Givens, R. G. Carlson, K. Srinivasachar, L. A. Sternson, T. Higuchi, Anal. Chem. 59 (1987) 1096-1101.

[14] V. Planté-Bordeneuve, J. Carayol, A. Ferreira, D. Adams, F. Clerget-Darpoux, M.

Misrahi, G. Said, C. Bonaïti-Pellie. J. Med. Genet. 2003, 40, 1-7.

[15] S. M. Johnson, S. Conelly, C.Fearns, E.T. Powers, J.W. Kelly, J.Mol. Biol. 421 (2012), 185-203

[16] Y. Ando, M. Nakamura, S. Araki, Arch. Neurol. 62 (2005) 1057-1062

[17] R. G. Carlson, K. Srinivasachar, R. S. Givens, B. K. Matuszewsky. J. Org. Chem. 51, (1986) 3978-3983.

[18] G. Rammouz, M. Lacroix, J. C. Garrigues, V. Poinsot, F. Couderc. Biomed. Chromatog. 21 (2007) 1223-1239.

[19] T. Hu, H. Zuo, C. M. Riley, J. F. Stobaugh, S. M. Lunte. J. Chromatogr A. 716 (1995) 381-388. 
[20] L.-Y. Zhang, Y.-M. Liu, Z.-L. Wang, J.-K. Cheng. Anal. Chem. Acta. 508 (2004) 141145 .

[21] V. A. Frerichs, J. K. Herrmann, A. Aguirre, L. A. Colon. Microchemical Journal, 78 (2004) $135-142$.

[22] M. A. Nussbaum, J. E. Przedwiecki, D. U. Staerk, Anal. Chem. 64 (1992) 1259-1263. 
Tables

\begin{tabular}{llll}
\hline $\begin{array}{l}\text { Amino } \\
\text { acid }\end{array}$ & $\begin{array}{l}\mathrm{E} \\
(\mathrm{mV})\end{array}$ & $\begin{array}{l}\mathrm{Sd}^{\mathrm{a}} \\
(\mathrm{mV})\end{array}$ & $\begin{array}{l}\mathrm{L}_{1 / 2}{ }^{\mathrm{b}} \\
(\mathrm{mV})\end{array}$ \\
\hline lysine & 540 & 3 & 170 \\
histidine & 570 & 4 & 240 \\
threonine & 580 & 5 & 210 \\
serine & 590 & 5 & 140 \\
\hline PN & $555^{\mathrm{c}}$ & 4 & 190 \\
& $690^{\mathrm{d}}$ & 6 & 190 \\
\hline
\end{tabular}

[a] Standard deviation. [b] Full-widths at mid-height. [c] TTR simply derivatized. [d] TTR doubly derivatized.

Table 1: Peak potential characteristics for the derivatized $25 \mu \mathrm{M}$ for each amino acid (AA$\mathrm{CBI}$ ) and for $25 \mu \mathrm{M}$ PN-CBI versus saturated calomel electrode. 


\section{Figure}

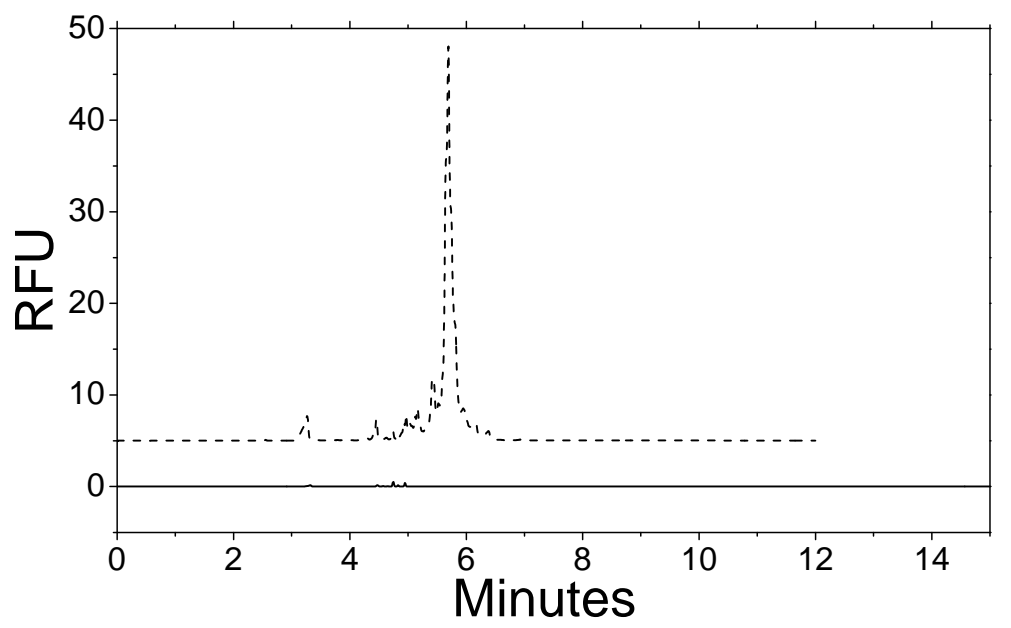

Fig. 1: Electropherograms of derivatized PN (top) and blank NDA: sample containing the reaction mixture except the peptide (bottom). Derivatization conditions: Peptide concentration $0.2 \mathrm{mmol} / \mathrm{L}, 50 \mathrm{mM}$ borate buffer $\mathrm{pH} 10, \mathrm{NDA} / \mathrm{PN}$ ratio=40. Electrophoretic conditions: silica capillary $(50 \mathrm{~cm}$ effective length, $57 \mathrm{~cm}$ total length and a $75 \mu \mathrm{m}$ inner diameter), $40 \mathrm{mM}$ HEPES buffer $\mathrm{pH} 8,25 \mathrm{kV}, 25^{\circ} \mathrm{C}$. LIF detection $\lambda \mathrm{ex}=442 \mathrm{~nm}$. For better legibility a shift of -5 RFU has been done with the blank. 


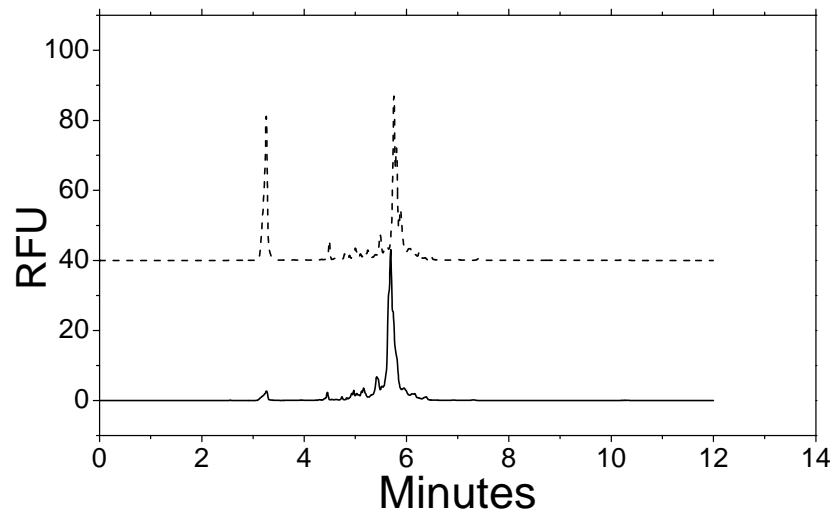

Fig. 2: Effect of the NDA/PN molar ratio on the derivatized PN electropherogram: $\mathrm{NDA} / \mathrm{PN}$ ratio $=100$ (top), NDA/PN ratio $=40$ (bottom). Derivatization and electrophoretic conditions are similar to these given in Fig. 1. 


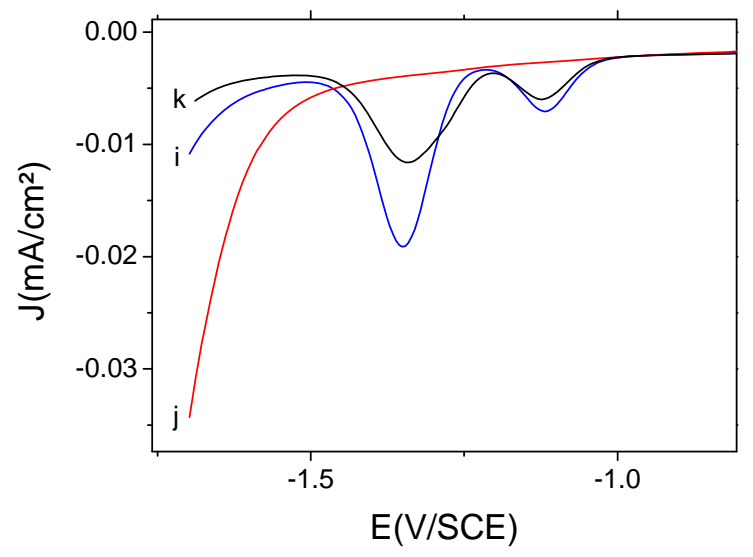

Fig. 3: $\mathrm{DPV}$ at $25 \mathrm{mV} / \mathrm{s}$ on glassy carbon $\left(\mathrm{S}=0,071 \mathrm{~cm}^{2}\right)$ in $100 \mathrm{mM}$ borate buffer at $\mathrm{pH}=9$.. Reductive potential window (i) $2.5 \mathrm{mM}$ NDA in methanol:water (50:50 v/v) (j) $25 \mu \mathrm{M}$ PN (k) $25 \mu \mathrm{M}$ PN derivatization with $2.5 \mathrm{mM}$ NDA NDA/PN molar ratio of 100 . 


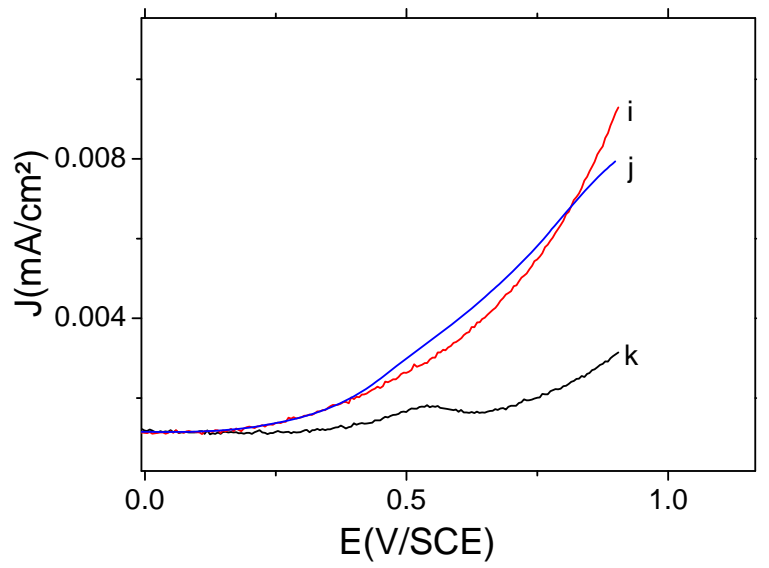

Fig. 4: $\mathrm{DPV}$ at $25 \mathrm{mV} / \mathrm{s}$ on glassy carbon $\left(\mathrm{S}=0,071 \mathrm{~cm}^{2}\right)$ in $100 \mathrm{mM}$ borate buffer at $\mathrm{pH}=9$.. Oxidative potential window (i) $2.5 \mathrm{mM}$ NDA in methanol:water $(50: 50 \mathrm{v} / \mathrm{v})(\mathrm{j}) 25 \mu \mathrm{M}$ PN (k) $25 \mu \mathrm{M}$ PN derivatization with $2.5 \mathrm{mM}$ NDA NDA/PN molar ratio of 100 . 


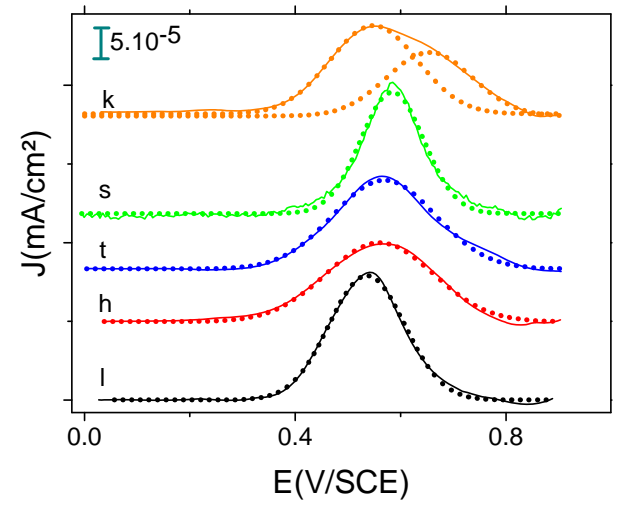

Fig. 5: $\mathrm{DPV}$ at $25 \mathrm{mV} / \mathrm{s}$ on glassy carbon $\left(\mathrm{S}=0,071 \mathrm{~cm}^{2}\right)$ in $100 \mathrm{mM}$ borate buffer at $\mathrm{pH}=9$. (h) CBI-(histidine), $2.5 \mathrm{mM}$ NDA/ $25 \mu \mathrm{M}$ histidine $=100$. (l) CBI-(lysine), $2.5 \mathrm{mM} \mathrm{NDA} /$ $25 \mu \mathrm{M}$ lysine $=100$. (t) CBI-(threonine), $2.5 \mathrm{mM} \mathrm{NDA} / 25 \mu \mathrm{M}$ threonine $=100$, (s) CBI(serine), $2.5 \mathrm{mM} \mathrm{NDA} / 25 \mu \mathrm{M}$ serine $=100,(\mathrm{k}) \mathrm{CBI}-(\mathrm{PN}), 2.5 \mathrm{mM} \mathrm{NDA} / 25 \mu \mathrm{M}$ PN $=100$. 

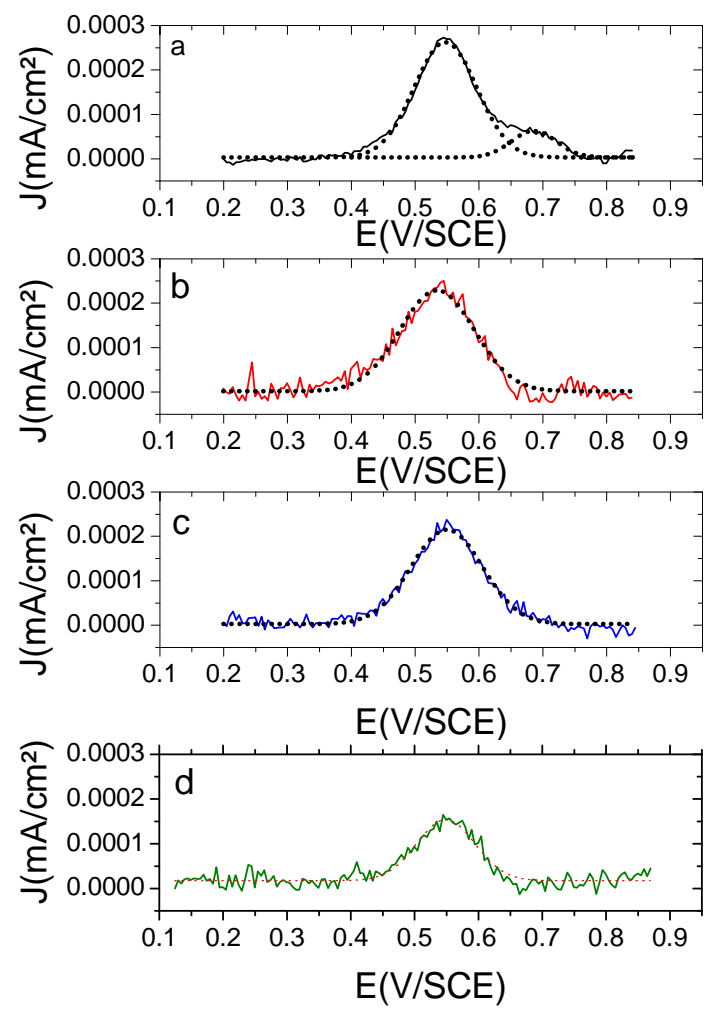

Fig. 6: DPV of CBI-PN : (a) borate buffer $\mathrm{pH}=10,2.5 \mathrm{mM}$ NDA/ $25 \mu \mathrm{M}$ PN molar ratio 100, (b) borate buffer $\mathrm{pH}=9,1 \mathrm{mM} \mathrm{NDA} / 25 \mu \mathrm{M}$ PN molar ratio 40, (c) borate buffer $\mathrm{pH}=10,1 \mathrm{mM}$ NDA/ $25 \mu \mathrm{M}$ PN molar ratio 40 , (d) $10 \mu \mathrm{M}$ PN in borate buffer $\mathrm{pH}=10,0.4$ $\mathrm{mM}$ NDA/ $10 \mu \mathrm{M}$ PN molar ratio 40. Scan rate $25 \mathrm{mV} / \mathrm{s}$ modultation time $100 \mathrm{~ms}$ modulation amplitude $7.5 \mathrm{mV}$. 

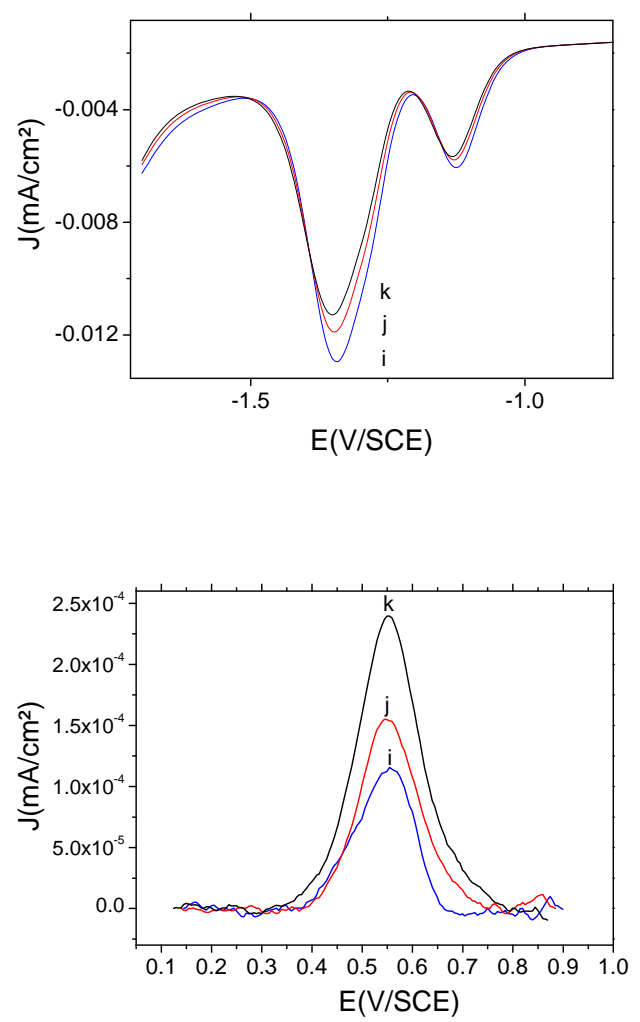

Fig. 7: (A). DPV of CBI-PN Reductive potential window for $1 \mathrm{mM}$ NDA/ $25 \mu \mathrm{M}$ PN (i) derivatization time of $3 \mathrm{~min}(\mathrm{j})$ derivation time of $9 \min (\mathrm{k})$ derivatization time of $15 \mathrm{~min}$. (B). DPV of CBI-PN oxidative potential window (i) derivatization time of $3 \mathrm{~min}$ (j) derivation time of 9 min $(\mathrm{k})$ derivatization time of $15 \mathrm{~min}$. 